\title{
Thermal and Chemical Characterization of Kenaf Fiber (Hibiscus cannabinus) Reinforced Epoxy Matrix Composites
}

\author{
Thuane Teixeira da Silva ${ }^{1}{ }^{(0)}$, Pedro Henrique Poubel Mendonça da Silveira $\left.{ }^{1}{ }^{(}\right)$, Matheus Pereira Ribeiro ${ }^{1}$, \\ Maurício Ferrapontoff Lemos ${ }^{2}\left(\mathbb{D}\right.$, Ana Paula da Silva ${ }^{2}$, Sergio Neves Monteiro ${ }^{1, * \mathbb{C}}$ and \\ Lucio Fabio Cassiano Nascimento ${ }^{1}$ (1)
}

1 Department of Materials Science, Military Institute of Engineering-IME, Praça General Tibúrcio 80, Urca, Rio de Janeiro 22290-270, Brazil; thuaneteixeiraa@gmail.com (T.T.d.S.); pedroo.poubel@gmail.com (P.H.P.M.d.S.); mpmatheusr@gmail.com (M.P.R.); lucio_coppe@yahoo.com.br (L.F.C.N.)

2 Brazilian Navy Research Institute-IPqM, Materials Technology Group; Rua Ipiru, 02, Cacuia, Rio‘de Janeiro 21931-095, Brazil; mauricio.lemos@marinha.mil.br (M.F.L.); silva.ana@marinha..mil.br (A.P.d.S.)

* Correspondence: snevesmonteiro@gmail.com

check for updates

Citation: Silva, T.T.d.; Silveira, P.H.P.M.d.; Ribeiro, M.P.; Lemos, M.F.; da Silva, A.P.; Monteiro, S.N.;

Nascimento, L.F.C. Thermal and Chemical Characterization of Kenaf Fiber (Hibiscus cannabinus) Reinforced Epoxy Matrix Composites. Polymers 2021, 13, 2016. https://doi.org/ $10.3390 /$ polym 13122016

Academic Editor: Carlo Santulli

Received: 21 May 2021

Accepted: 16 June 2021

Published: 20 June 2021

Publisher's Note: MDPI stays neutral with regard to jurisdictional claims in published maps and institutional affiliations.

Copyright: (c) 2021 by the authors. Licensee MDPI, Basel, Switzerland. This article is an open access article distributed under the terms and conditions of the Creative Commons Attribution (CC BY) license (https:/ / creativecommons.org/licenses/by/ $4.0 /)$.

\begin{abstract}
Kenaf (Hibiscus cannabinus L.) is one of the most investigated and industrially applied natural fibers for polymer composite reinforcement. However, relatively limited information is available regarding its epoxy composites. In this work, both thermal and chemical properties were, for the first time, determined in kenaf fiber reinforced epoxy matrix composites. Through XRD analysis, a microfibrillar angle of $7.1^{\circ}$ and crystallinity index of $44.3 \%$ was obtained. The FTIR analysis showed the functional groups normally found for natural lignocellulosic fibers. TMA analysis of the composites with $10 \mathrm{vol} \%$ and $20 \mathrm{vol} \%$ of kenaf fibers disclosed a higher coefficient of thermal expansion. The TG/DTG results of the epoxy composites revealed enhanced thermal stability when compared to plain epoxy. The DSC results corroborated the results obtained by TGA, which indicated a higher mass loss in the first stage for kenaf when compared to its composites. These results might contribute to kenaf fiber composite applications requiring superior performance.
\end{abstract}

Keywords: natural fibers; kenaf; epoxy composite materials; thermal degradation properties; chemical characterization

\section{Introduction}

Sustainable composites reinforced with natural fibers are drawing increasing attention in both research works [1-7] and industrial applications [8-14]. This recognition is due to the natural fiber characteristics, such as cost effectiveness, biodegradability, recyclability, and renewability. Relevant properties are associated with natural fiber composites (NFCs), such as a high degree of flexibility, hygroscopicity, and reduced energy consumption for production due to less abrasiveness to processing equipment.

NFCs specific mechanical properties are comparable to those of synthetic fiber composites like fiberglass, as the density of natural lignocellulosic fibers $\left(<1.6 \mathrm{~g} / \mathrm{cm}^{3}\right)$ is significantly lower than that of glass fiber $\left(2.58 \mathrm{~g} / \mathrm{cm}^{3}\right)$ [15]. In particular, "Life Cycle Engineering" [16] is able to show the advantages of considering NFCs in terms of environmental and financial impact for designers and engineers to include these materials in future projects emphasizing sustainability strategies.

In this century, kenaf fiber has been one of the most investigated and industrially applied natural lignocellulosic fibers for reinforcement of polymer composites [17]. It has recently been investigated as a possible reinforcement of sustainable composites even as short discontinuous fibers [18]. The kenaf fiber is extracted from Hibiscus cannabinus, illustrated in Figure 1, an herbaceous plant from the family of Malvaceae, native to Africa 
and India. The kenaf crop is resistant to semiarid conditions such as those found in the Mediterranean region, which allows achieving significant above-ground production rates with a consumption of only 500-600 mm of rain water in 6 months [17].
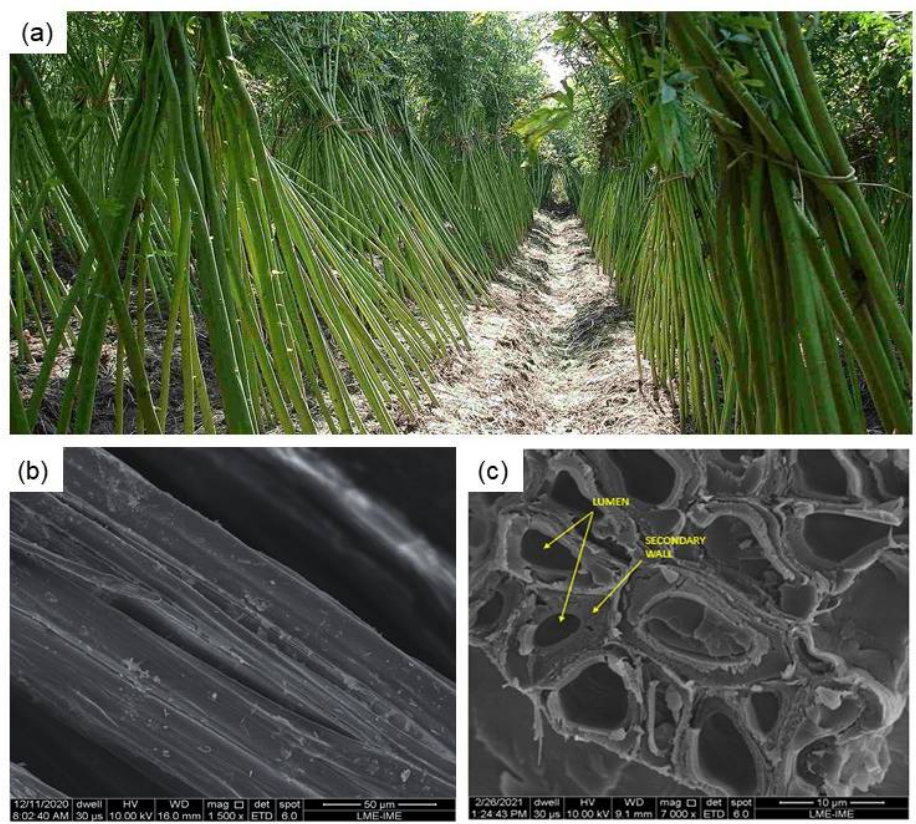

Figure 1. (a) Kenaf plants; (b) SEM image of a longitudinal section of the kenaf fiber; (c) SEM image of a cross-section of the kenaf fiber indicating the lumen and secondary walls of the fiber.

Various commercial products such as high-quality papers, biocomposites for car door trimmings, interior shelving, bioplastics, building materials like medium-density fiberboard, textile, furniture, and many others have already been developed based on the physical and mechanical performance of kenaf fibers [19].

Although the kenaf fiber presents recognized disadvantages inherent to natural lignocellulosic fibers, it is comparatively a promising reinforcement for polymer composites. The cellulose content $(31 \%-72 \%)$ and microfibrillar angle $\left(9^{\circ}-15^{\circ}\right)$ influence the mechanical properties of the kenaf fiber, leading to relatively higher tensile strength $[17,19]$. As such, it was found that polypropylene (PP) composites reinforced with kenaf fiber display superior tensile and flexural strength when compared with those of other PP composites reinforced, for example, with hemp, sisal, and even glass fiber. This led to its application as an automotive structural component [20].

Actually, kenaf-reinforced composites have used a diversified number of polymer matrices including PP [21-29], polyester [30-36], polyurethane [37,38], high-density polyethylene [22,39-41], polystyrene [42], polylactic acid [43-51], natural rubber [52], PVC [53], and epoxy [54] among others.

In particular, epoxy matrix reinforced with kenaf fiber was investigated for different purposes. Park et al. [54] evaluated the micromechanical properties of epoxy / kenaf composites and the wettability of kenaf fibers using non-destructive acoustic emission. Keshk et al. [55] performed physicochemical characterization of kenaf fibers to identify their chemical composition (cellulose, hemicellulose, and lignin) and their physical properties (viscosity, degree of polymerization, and crystallinity).

Sgriccia and Hawley [56] reported the characterization of epoxy composites with $15 \mathrm{wt} \%$ of kenaf fiber to verify the effectiveness of curing the composite using the microwave method. Chin et al. [57] investigated the potential of vacuum-processed epoxy/kenaf composites in tribological application. Xue et al. [58] reported on improved mechanical properties (modulus of elasticity, tensile strength) of epoxy composites reinforced with kenaf Liberian fibers. Abu Bakar et al. [59] investigated the mechanical and morphological properties of 
epoxy composites reinforced with kenaf fiber treated through mercerization with $\mathrm{NaOH}$. Mutasher et al. [60] showed the effect of alkaline mercerization treatment on kenaf fibers on the tensile strength and flexural strength of epoxy/kenaf composites. Abdullah et al. [61] reported on the fatigue behavior of unidirectional epoxy/kenaf composites prepared by hand lay-up. Suriani at al. [62] detected defects in kenaf/epoxy composite using infrared thermal imaging.

It is also worth mentioning the investigation by Davoodi et al. [63] on the mechanical properties of hybrid kenaf/glass-reinforced epoxy composite for application in car bumper beams. Ali Kandemir et al. [18] investigated the adhesion, physical, and mechanical properties of epoxy matrix composites reinforced with discontinuous kenaf fibers, where their performance was compared with other fibers.

Despite these valuable research works, to our knowledge, no systematic investigation has been conducted, so far, on the combined thermal and chemical behavior of kenaf fiber reinforced epoxy composites to establish technical limits for possible industrial applications. The limited information on epoxy composites might be attributed to the relatively higher cost as compared to the other polymer resins. However, for high-performance applications, epoxy provides good adhesion to the reinforcing filler and improved enhanced mechanical properties in association with its low moisture content, less shrinkage upon curing, and easy room temperature processing [64].

Motivated by the aforementioned current status, the present work investigates the thermal and chemical characterization of epoxy composites reinforced with up to $30 \mathrm{vol} \%$ of continuous and aligned kenaf fibers.

\section{Materials and Methods}

\subsection{Materials}

The kenaf fibers illustrated in Figure 2 were supplied by Tapetes São Carlos Ltd., São Paulo, Brazil.
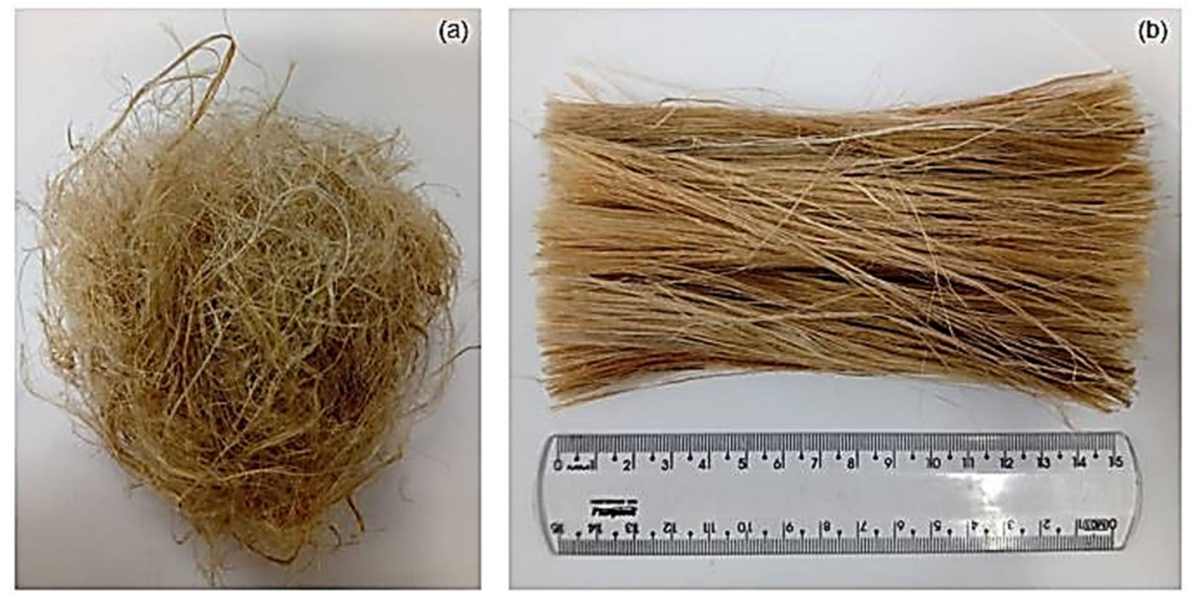

Figure 2. Kenaf fibers (a) as received; (b) after cleaning and separating the fibers.

Table 1 presents the basic properties of the as-supplied kenaf fibers applied in the present work to reinforce epoxy composites. The density of the kenaf fibers was obtained by calculating the mass using an analytical scale model AG-200 from Gehaka (São Paulo, Brazil) with a precision of $0.0001 \mathrm{~g}$ divided by the volume $\left(\pi \mathrm{D}^{2} / 4 \times 150\right)$ of 100 fibers. The fiber diameter $(D)$ values were measured by visualization under the profile projector of an optical microscope model BX53M from Olympus (Münster, Germany). 
Table 1. Properties of the as-supplied kenaf fibers and the DGEBA/TETA epoxy.

\begin{tabular}{cccccc}
\hline Properties & Density $\left(\mathbf{g} / \mathbf{c m}^{\mathbf{3}}\right)$ & $\begin{array}{c}\text { Average Fiber } \\
\text { Diameter }(\boldsymbol{\mu m})\end{array}$ & $\begin{array}{c}\text { Tensile Strength } \\
\mathbf{( M P a )}\end{array}$ & $\begin{array}{c}\text { Young's Modulus } \\
\mathbf{( G P a )}\end{array}$ & $\begin{array}{c}\text { Total Elongation } \\
\mathbf{( \% )}\end{array}$ \\
\hline Kenaf Fiber & $1.52 \pm 0.28$ & $71.2 \pm 6.0$ & $577 \pm 71$ & $33.8 \pm 3.9$ & $1.7 \pm 0.2$ \\
Resin Epoxy & $1.11 \pm 0.05$ & - & $50 \pm 8.4$ & $2.7 \pm 0.35$ & $2.5 \pm 0.4$ \\
\hline
\end{tabular}

The results of the fiber density and diameter measurements are further shown in Section 3.1, and the mechanical properties were provided by the supplier. A commercial epoxy resin, diglycidyl ether of bisphenol A (DGEBA)-type hardened with triethylenetetramine (TETA) in a 13 phr stoichiometric ratio, fabricated by Dow Chemical, São Paulo, Brazil, and distributed by Resinpoxy Ltd, Rio de Janeiro, Brazil, was used as a polymeric matrix. Related information on DGEBA/TETA epoxy may be assessed at [65-67].

\subsection{Composites Processing}

The as-received kenaf fibers (Figure 2a) were first cleaned by immersing in water for $24 \mathrm{~h}$ to remove impurities. After immersion, the fibers were dried in a stove at $70{ }^{\circ} \mathrm{C}$ for $24 \mathrm{~h}$. The fibers were separated and cut in a length of $150 \mathrm{~mm}$ (Figure 2b) for proper insertion in the mold for composite fabrication.

The composite plates production was done by compression, using a steel mold with rectangular dimensions of $150 \times 120 \times 12 \mathrm{~mm}^{3}$. The kenaf fibers were unidirectionally laid into the mold with the still liquid epoxy-hardener mixture in a previously calculated fiber-to-resin ratio. DGEBA/TETA epoxy composites incorporated with 10, 20, and $30 \mathrm{vol} \%$ of kenaf fiber, as shown in Figure 3, were fabricated using the epoxy and fiber densities listed in Table 1 to precisely determine the corresponding volume fractions. A plain epoxy plate (Figure 3a) was also fabricated as control. The composite plates were maintained under a 5-ton load in a SKAY hydraulic press (São Paulo, Brazil) for 24 h of curing.

(a)

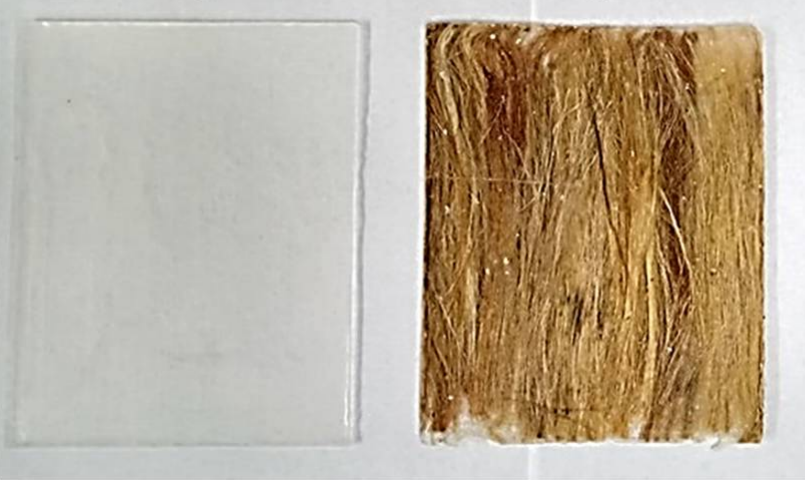

(c)

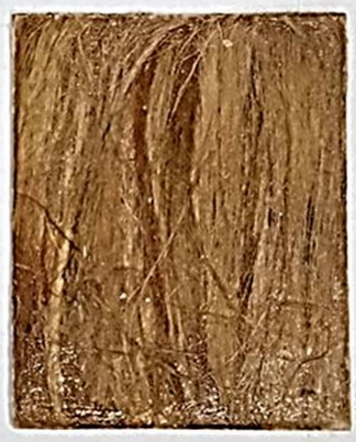

(d)

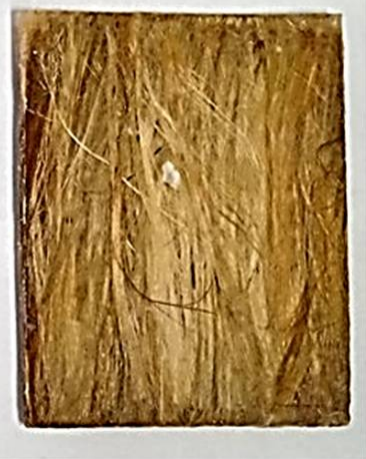

Figure 3. Plates produced: (a) 0; (b) $10 \mathrm{vol} \%$; (c) $20 \mathrm{vol} \%$ and (d) $30 \mathrm{vol} \%$ kenaf fibers.

Although the composite plates in Figure $3 \mathrm{~b}-\mathrm{d}$ might not show perfectly aligned kenaf fibers, based on our experience, this is the best unidirectional alignment obtained by hand laying of natural fibers in a $150 \mathrm{~mm}$ long mold. During the introduction of fluid epoxy, it is typical for some fibers to slightly deviate from the alignment due to fluid flow.

\subsection{Characterization}

\subsubsection{Thermogravimetric Analysis (TG/DTG)}

The thermogravimetric analyses of the epoxy, kenaf fibers, and the composites were performed in a Shimadzu DTG-60H machine (Tokyo, Japan). The samples were carefully hand-crushed with a pestle/mortar and then were placed in a platinum crucible. The procedure was performed under a nitrogen atmosphere with a heating rate of $10^{\circ} \mathrm{C} / \mathrm{min}$, 
from $20{ }^{\circ} \mathrm{C}$ to $700{ }^{\circ} \mathrm{C}$ for the kenaf fiber and epoxy, as well as from $20{ }^{\circ} \mathrm{C}$ to $900{ }^{\circ} \mathrm{C}$ for the composites, according to ASTM E1131 [68]. As aforementioned in Section 2.2, prior to TGA analysis, the as-supplied kenaf fibers were cleaned and dried to remove impurities. However, owing to their hydrophilic behavior, the fibers surface immediately absorbs air humidity that appears in the TGA results.

\subsubsection{Fourier Transform Infrared Spectroscopy (FTIR)}

FTIR analysis was performed to analyze the changes and interactions in the chemical bonding of kenaf fibers. FTIR spectra were recorded on NicoletiS10 equipment (ThermoFisher Scientific, Waltham, MA, USA) in a range of $500-4000 \mathrm{~cm}^{-1}$ with a resolution of $8 \mathrm{~cm}^{-1}$. The samples were comminuted and pressed under $10 \mathrm{kgf} / \mathrm{cm}$ pressure for $5 \mathrm{~min}$, forming $\mathrm{KBr}$ pellets.

\subsubsection{Differential Scanning Calorimetry (DSC)}

DSC tests were carried out in a DSC-60 machine from Shimadzu (Tokyo, Japan) under a nitrogen atmosphere with a heating rate of $10{ }^{\circ} \mathrm{C} / \mathrm{min}$ and a temperature range from $20^{\circ} \mathrm{C}$ to $400{ }^{\circ} \mathrm{C}$ for all the samples.

\subsubsection{X-ray Diffraction (XRD)}

The XRD analysis was performed in a Shimadzu XRD-6000 diffractometer (Tokyo, Japan) with $\mathrm{CuK} \alpha$ radiation, power of 1200 watts, $-40 \mathrm{KV}$ X $30 \mathrm{~mA}$, and performing a $2 \theta$ scan from 5 to 80 degrees. The microfibril angle (MFA) was calculated using the methodology proposed by Donaldson [69] and Sarén and Serimaa [70] through the deconvolution of the crystalline cellulose peak ( 002$)$. The calculation of fiber crystallinity follows the methodology presented by Segal et al. [71], where the maximum intensity obtained in the diffractogram is used for the area of the amorphous $\left(\begin{array}{lll}1 & 0 & 1\end{array}\right)$ and crystalline $\left(\begin{array}{lll}0 & 0\end{array}\right)$ peaks. These two peaks are associated with the amorphous $\left(\mathrm{I}_{\mathrm{am}}\right)$ and crystalline $\left(\mathrm{I}_{\text {crys }}\right)$ phases, respectively. The crystallinity index of the fiber is calculated by:

$$
\mathrm{CrI}=\left(\frac{\mathrm{I}_{\text {crys }}-\mathrm{I}_{\mathrm{am}}}{\mathrm{I}_{\text {crys }}}\right) \times 100 \%
$$

\subsubsection{Thermomechanical Analysis (TMA)}

The measurements of the linear thermal expansion coefficient of the resin and the kenaf composite were performed with TMA-60 equipment (Shimadzu, Tokyo, Japan). The test was carried out according to ASTM E831 [72] under nitrogen atmosphere with a temperature range from $20^{\circ} \mathrm{C}$ to $200^{\circ} \mathrm{C}$ and a compression load of $10 \mathrm{gf}$.

\section{Results and Discussion}

\subsection{Kenaf Fiber Density}

The average density was obtained from the ratio between mass and volume in 100 as-supplied kenaf fibers. The mass of each fiber was determined on a precision scale. The corresponding fiber volume was calculated from its diameter measured in 10 points along its length in an optical microscope projector. For all 100 fibers, the average diameter was found as $71.2 \pm 6.0 \mu \mathrm{m}$ resulting in an average density of $1.52 \pm 0.28 \mathrm{~g} / \mathrm{cm}^{3}$.

\subsection{Thermogravimetric Analysis (TGA)}

Through TGA, it was possible to observe the mass loss process of the epoxy, kenaf fiber, and its composites with temperature. Figure 4 shows the TG/DTG curves for the DGEBA/TETA epoxy and the kenaf fiber. Beyond $700{ }^{\circ} \mathrm{C}$, the TG curve remained horizontally constant, indicating no further mass loss. 

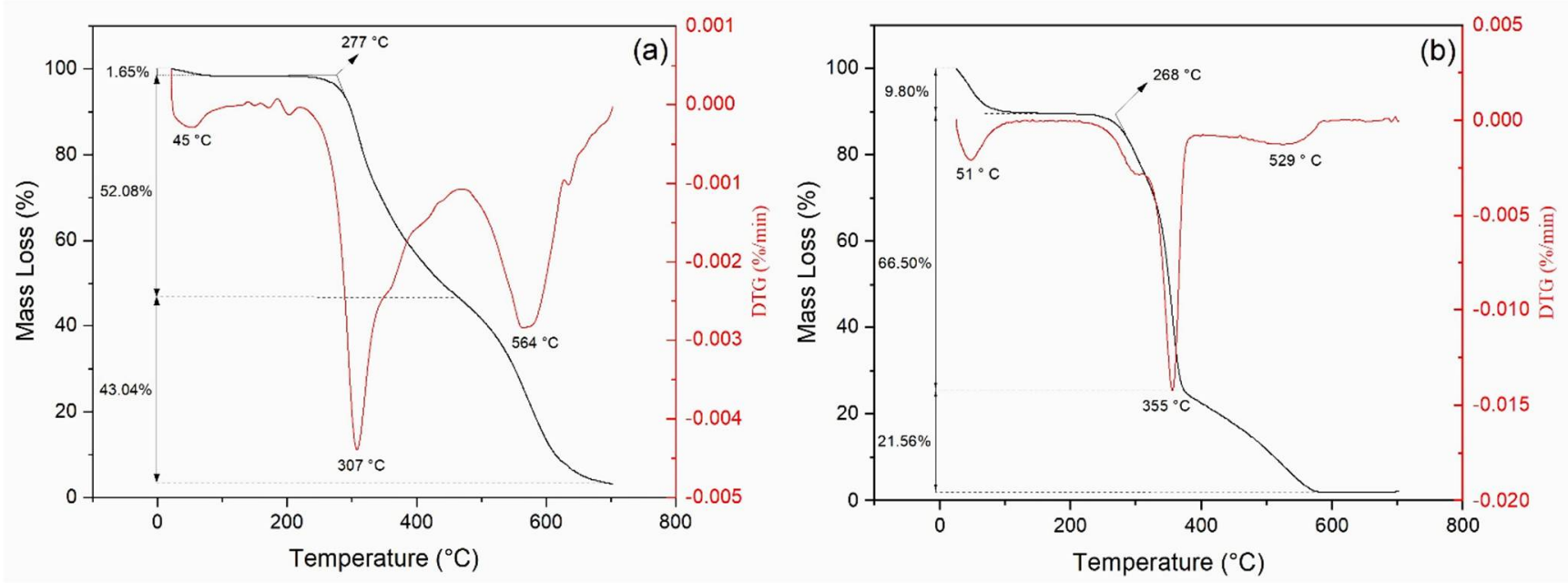

Figure 4. TG and DTG curves for (a) epoxy resin; (b) kenaf fibers.

In Figure 4a, a $1.65 \%$ mass loss of the epoxy is observed in the first stage (up to $150^{\circ} \mathrm{C}$ ), probably associated with the released humidity present in the synthetic polymer resin. The epoxy DTG curve displays prominent peaks associated with maximum mass loss rate at $307^{\circ} \mathrm{C}$ and at $564^{\circ} \mathrm{C}$, which is attributed to subsequent depolymerization and degradation of the polymeric chains.

The TG curve of kenaf fiber, Figure $4 b$, is also composed of three stages, where the first $\left(30\right.$ to $150{ }^{\circ} \mathrm{C}$ ) is most probably related to the loss of surface humidity (about $9.80 \%$ ). Natural fibers are known by its higher hydrophilicity. The greater degradation event of the fiber occurs in the second stage from $200{ }^{\circ} \mathrm{C}$ to about $570{ }^{\circ} \mathrm{C}$, with a maximum mass loss rate at $355^{\circ} \mathrm{C}$ associated with the loss of structural components of the fiber, mainly lignin, hemicellulose, and cellulose [73].

As for the DTG curve in Figure 4 (b), the small peak at $51^{\circ} \mathrm{C}$ can be assigned to loss of kenaf fiber surface moisture, while the sharp peak at $355{ }^{\circ} \mathrm{C}$ and its shoulder around $300{ }^{\circ} \mathrm{C}$ are attributed to the degradation of cellulose and hemicellulose. The spread peak, as a bump around $500{ }^{\circ} \mathrm{C}-600{ }^{\circ} \mathrm{C}$, might be related to lignin degradation [56].

Figure 5 shows the TG/DTG curves obtained for the kenaf composites. In the first degradation stage $\left(25\right.$ to $\left.150{ }^{\circ} \mathrm{C}\right)$, it is observed that the loss of mass increased with increasing fiber content, as expected, since epoxy presents a hydrophobic nature.
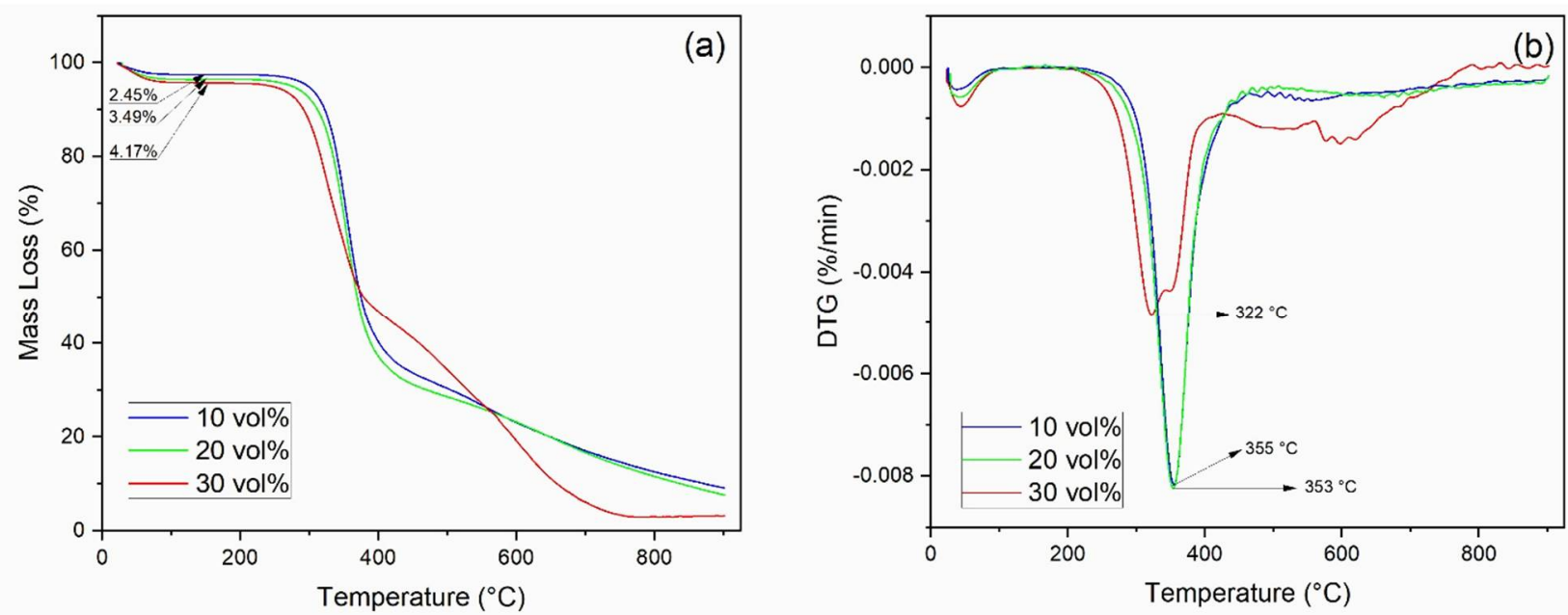

Figure 5. (a) TG curves of composites; (b) DTG curves of composites. 
Table 2 presents the main TGA parameters obtained for kenaf fiber, plain epoxy, and the investigated composites. The onset of thermal degradation $\left(T_{\text {onset }}\right)$ was obtained by the estimated point of deviation from the initial slope, almost a horizontal line in the TG curves of Figure 4 (epoxy and kenaf fiber) and Figure 5 (composites).

Table 2. Degradation temperatures and mass loss for kenaf fibers and composites.

\begin{tabular}{|c|c|c|c|c|c|c|c|}
\hline \multirow{2}{*}{ Sample } & \multirow{2}{*}{$\mathrm{T}_{\text {onset }}\left({ }^{\circ} \mathrm{C}\right)$} & \multirow{2}{*}{$\mathrm{T}_{\min }\left({ }^{\circ} \mathrm{C}\right)$} & \multirow{2}{*}{$\mathrm{T}_{\max }\left({ }^{\circ} \mathrm{C}\right)$} & \multicolumn{4}{|c|}{ Mass Loss (\%) } \\
\hline & & & & Stage I & Stage II & Stage III & Residue at \\
\hline Kenaf & 216 & 268 & 355 & 9.80 & 66.50 & 21.56 & $2.14\left(700^{\circ} \mathrm{C}\right)$ \\
\hline Epoxy & 218 & 277 & 307 & 1.65 & 52.08 & 43.92 & $2.35\left(700^{\circ} \mathrm{C}\right)$ \\
\hline $10 \mathrm{vol} \%$ & 237 & 302 & 355 & 2.45 & 62.93 & 25.52 & $9.10\left(900^{\circ} \mathrm{C}\right)$ \\
\hline $20 \mathrm{vol} \%$ & 235 & 299 & 353 & 3.49 & 64.41 & 24.50 & $7.60\left(900^{\circ} \mathrm{C}\right)$ \\
\hline $30 \mathrm{vol} \%$ & 230 & 293 & 322 & 4.17 & 51.01 & 41.63 & $3.19\left(900^{\circ} \mathrm{C}\right)$ \\
\hline
\end{tabular}

A minimum detected thermal degradation $\left(\mathrm{T}_{\min }\right)$ is proposed as the intercept between the initial, almost horizontal, slope and the steeper slope clearly related to the subsequent interval of thermal degradation of the material structure [73]. The point of maximun rate of thermal degradation $\left(\mathrm{T}_{\max }\right)$ is found as the DTG peak associated with the steeper region of mass loss, stage II on the TG curve.

Based on the values of $\mathrm{T}_{\text {onset }}$ in Table 2, it is possible to assume, in principle, that a safe maximum working temperature for the composite would be $200^{\circ} \mathrm{C}$, which is comparable to those of other natural fiber epoxy composites [73]. However, within the possible statistical variation of $T_{\text {onset }}$ that is to be determined by a repeated number of TGA tests for several kenaf composite samples, the working temperature might eventually be safely raised to $220^{\circ} \mathrm{C}$ as an upper limit.

In Table 2, it is worth noticing that enhancing the fiber content in the polymer is associated with a thermal stabilization of the composites. This is also corroborated by a higher residue content at $900{ }^{\circ} \mathrm{C}$, especially for the composites with $20 \mathrm{vol} \%$ and $30 \mathrm{vol} \%$ kenaf fiber. The relatively small amount of char residue for both kenaf fiber and plain epoxy in Table 2 is an indication of near total carbonization at $700{ }^{\circ} \mathrm{C}$. On the other hand, addition of kenaf fiber into the epoxy matrix enhances the composite thermal stability. This might be attributed to the fiber interaction, which is delaying the composite total degradation to higher temperatures. Indeed, at $900{ }^{\circ} \mathrm{C}$, the composites char residues $(3.19-9.10 \%)$ remain above those of kenaf fiber $(2.14 \%)$ and epoxy $(2.35 \%)$ found at $700{ }^{\circ} \mathrm{C}$.

Regarding the results shown in Figure 6 and Table 2, one should bear in mind that incorporation of natural fibers into polymer matrices does not behave as an additive rule of mixture for thermal properties. The fiber interation with macromolecular chains affects the polymer glass transition of temperature, which is decreased, and then causes a total amorphous structure to be formed at lower temperature. This allows thermal softening to be displaced to higher temperatures. 


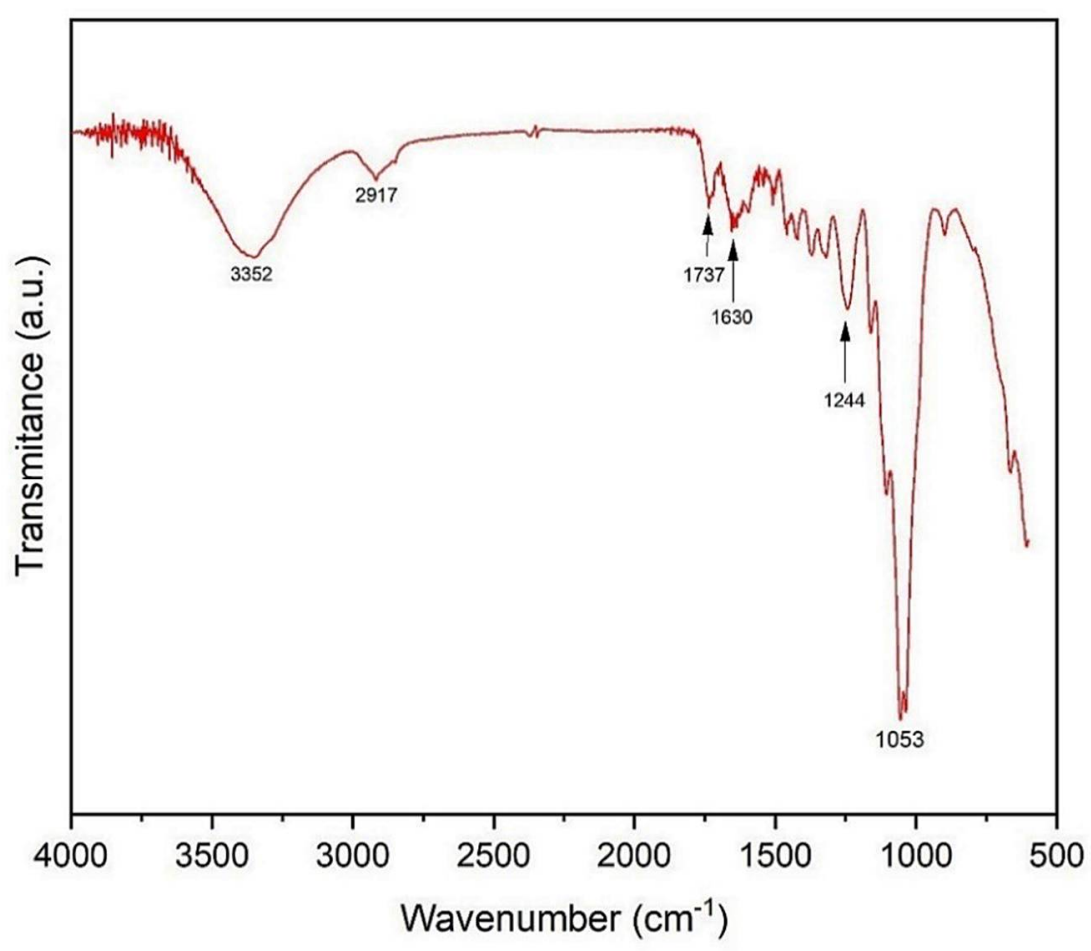

Figure 6. FTIR spectra of kenaf fiber.

\subsection{Fourier Transform Infrared Spectroscopy (FTIR)}

Figure 6 depicts the vibrational spectrum obtained from the comminuted sample of the kenaf fiber.

Natural fibers have cellulose and lignin as main elements, which present a hydroxyl functional group in their structure. The FTIR spectrogram shows a band at $3352 \mathrm{~cm}^{-1}$ related to the stretching of the $\mathrm{OH}$ connection, and the $2917 \mathrm{~cm}^{-1}$ represents the elongation of the symmetrical and asymmetric $\mathrm{CH}$ bond. This is related to aliphatic groups rich in cellulose and hemicellulose.

Another band at $1737 \mathrm{~cm}^{-1}$ corresponds to the ester carbonyl vibrations of the acetyl groups feruloyl and p-coumaril in lignin. An elongation band detected at $1650 \mathrm{~cm}^{-1}$ is assigned to the carbonyl group of the acetyl ester in hemicellulose and the carbonyl aldehyde in lignin. The broad band of $1244 \mathrm{~cm}^{-1}$ corresponds to the asymmetric $\mathrm{C}-\mathrm{O}$ vibration $[17,74,75]$.

The absorption band around $1053 \mathrm{~cm}^{-1}$ is related to the frequencies of $\mathrm{C}-\mathrm{O}$ and $\mathrm{C}-\mathrm{C}$ elongation of the xylans and elongation of the $\mathrm{C}-\mathrm{O}-\mathrm{C}$ glycosidic bond in hemicellulose. This band is also attributed to the $\mathrm{C}-\mathrm{O}$ elongation, originating from the $\mathrm{C}-\mathrm{O}-\mathrm{CH}_{3}$ groups, which reinforces the existence of hemicellulose and lignin in the kenaf fibers [76].

\subsection{Differential Scanning Calorimetry (DSC)}

Figure 7 shows the DSC curves for the investigated materials. In Figure 7a, a DSC endothermic peak with a minimum temperature of $72{ }^{\circ} \mathrm{C}$ is observed in association with loss of moisture from the epoxy resin, which occurs at a temperature higher than that obtained by TGA. Moreover, two exothermic peaks at $324^{\circ} \mathrm{C}$ and $352^{\circ} \mathrm{C}$ can be attributed to the degradation and rupture of polymer chains, corroborating the TGA results. 

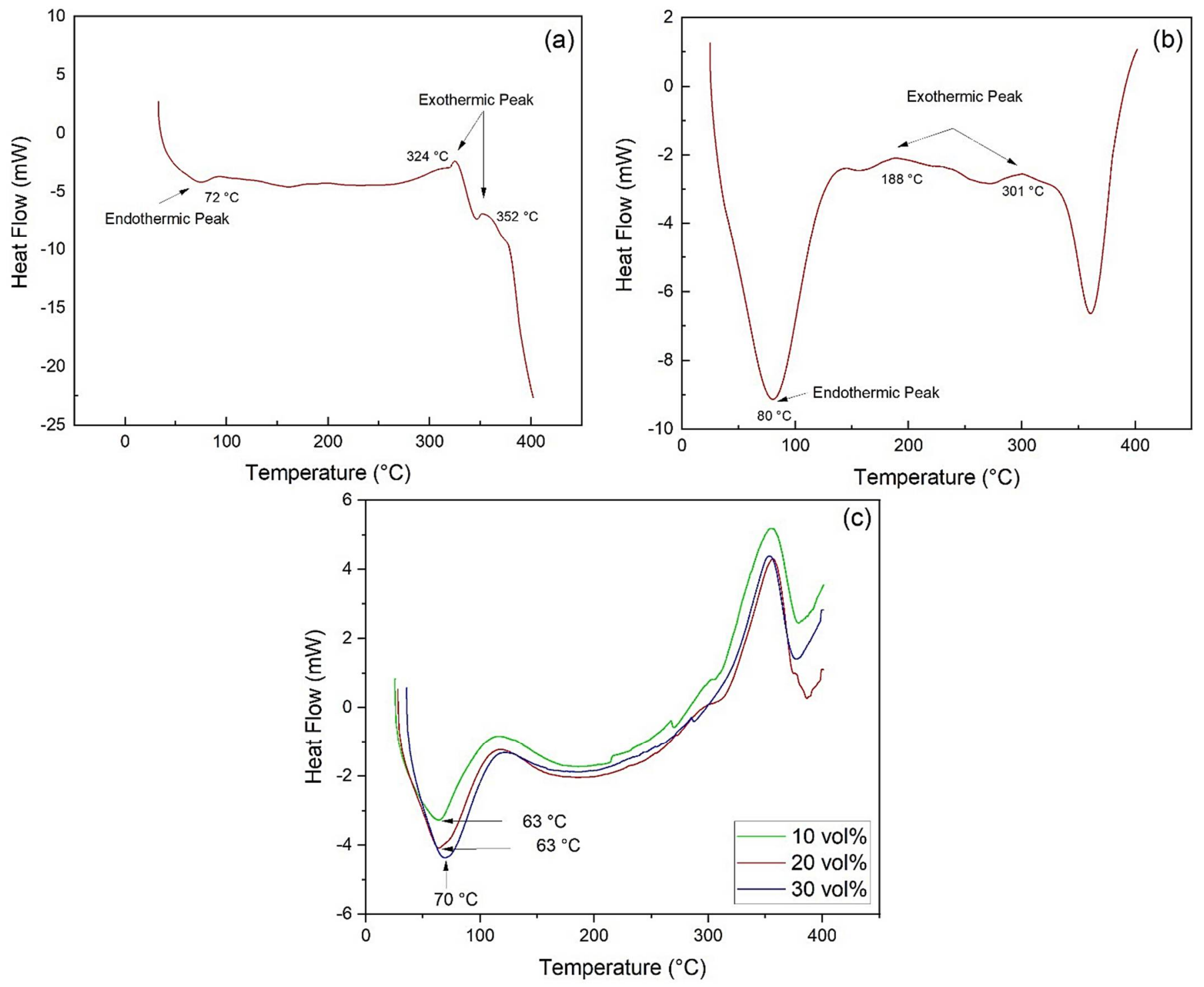

Figure 7. DSC curves: (a) epoxy resin; (b) kenaf fiber; (c) kenaf composites.

The DSC curve for kenaf fiber (Figure $7 \mathrm{~b}$ ) presents an endothermic peak with a minimum at $80^{\circ} \mathrm{C}$, referring to the loss of moisture in the fiber. Even though the DSC moisture peak occurred at a significantly different temperature $\left(51^{\circ} \mathrm{C}\right)$ than that obtained by TGA in Figure $4 b$, both are within a similar temperature range. Indeed, TGA refers to weight loss, while DSC depicts heat flow.

In both DTG (Figure 4b) and DSC (Figure 7b) curves, the kenaf fiber begins to lose mass and dissipate heat right from the beginning of the test at $20^{\circ} \mathrm{C}$. The maximum weight loss at $51{ }^{\circ} \mathrm{C}$ is mostly related to surface humidity release, and the DTG peak extends up to $100{ }^{\circ} \mathrm{C}$, when total moisture is evaporated. On the other hand, the heat flow from water evaporation is cumulative and reaches a maximum at $80^{\circ} \mathrm{C}$, close to the point where all moisture is gone. The endothermic peaks in Figure $7 \mathrm{~b}$ are correlated to the beginning of the decomposition of cellulose and hemicellulose $\left(188^{\circ} \mathrm{C}\right)$ and lignin $\left(301^{\circ} \mathrm{C}\right)$, which takes longer to start the decomposition.

The DSC curves obtained for the epoxy matrix composites with $10 \mathrm{vol} \%, 20 \mathrm{vol} \%$, and $30 \mathrm{vol} \%$ kenaf are shown in Figure $7 \mathrm{c}$. These curves corroborate what was observed in the TGA analysis, with the endothermic peak starting at $20{ }^{\circ} \mathrm{C}$ with minimum, at $63{ }^{\circ} \mathrm{C}$ for composites with $10 \mathrm{vol} \%$ and $20 \mathrm{vol} \%$ of fibers, and $70^{\circ} \mathrm{C}$ for the $30 \mathrm{vol} \%$ composite. 
The peaks occurring at temperatures lower than those of the resin and fiber are due to the earlier loss of moisture in the composites.

\subsection{X-ray Diffraction (XRD)}

The XRD patterns were analyzed by computational treatment of the data using the OriginPro software. The diffractogram obtained for the kenaf fiber is shown in Figure 8.

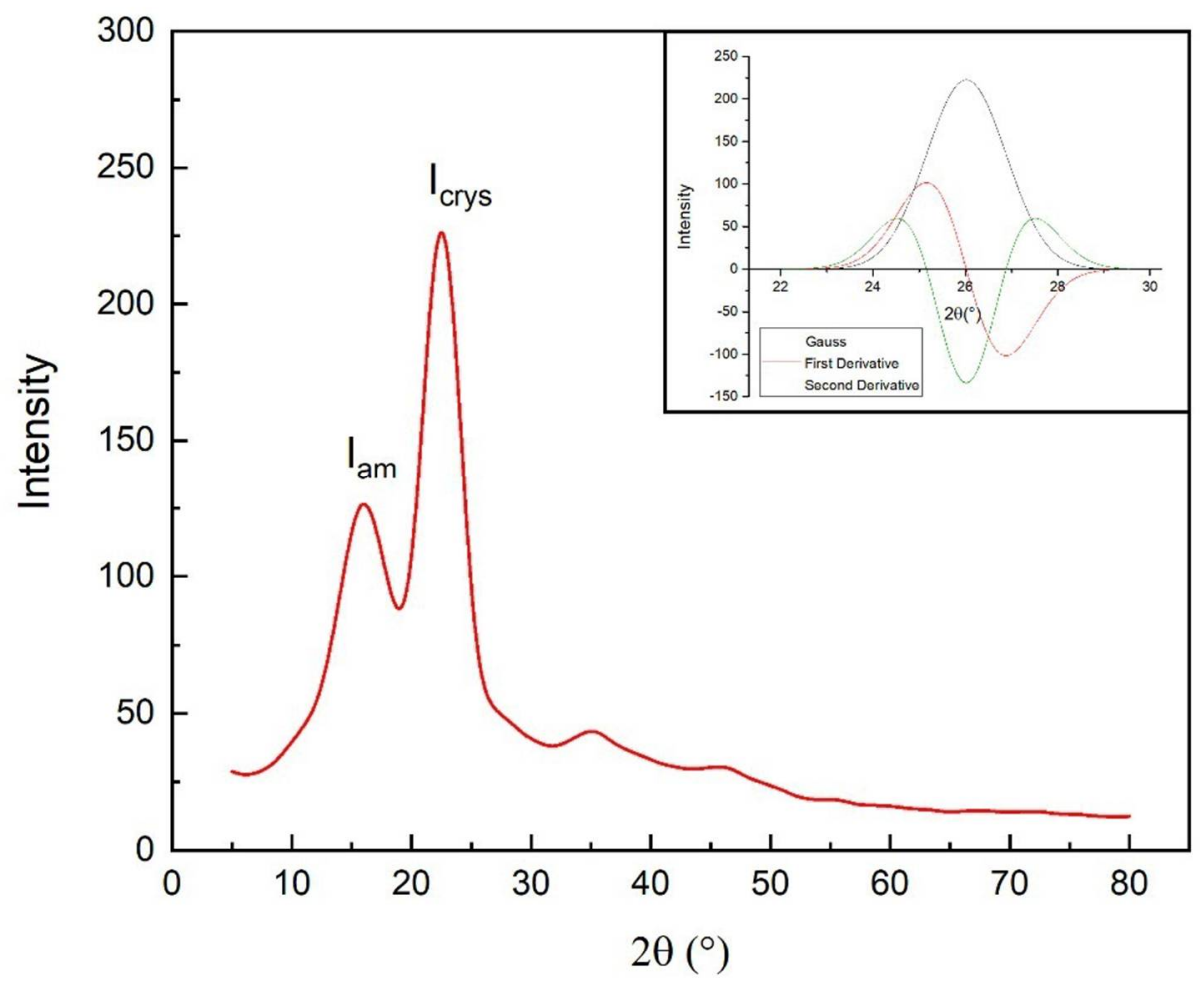

Figure 8. X-ray diffractogram of kenaf fiber. Insertion: deconvolution for calculation of the microfibrillar angle (MFA).

For the determination of $\mathrm{CrI}$, the peak intensity values associated with the amorphous and crystalline phases were used in Equation 1. Then, using the OriginPro software, normalization and derivation of the highest-intensity peak were performed for the calculation of the microfibrillar angle (MFA).

The MFA of kenaf fibers was found to vary from 9 to $15^{\circ}$ [19]. In this work, the MFA was $7.1^{\circ}$, a value that is lower than those found in the literature and close to ramie, hemp, and jute fibers. [77].

A comparatively lower MFA indicates a relatively stronger natural fiber [69]. The apparent difference between the MFA of $7.1^{\circ}$ found in the present work, and that between $9^{\circ}$ and $15^{\circ}$ reported elsewhere [19], indicates that kenaf fiber from distinct origins (region, soil, crop, or season) might have different physical characteristics and mechanical properties. This is commonly verified in natural fibers of the same species [78].

The CrI for the present untreated kenaf fiber is only $44.3 \%$, which implies a substantial presence of amorphous substances in the fiber.

\subsection{Thermomechanical Analysis (TMA)}

Figure 9 presents the TMA curves for the epoxy resin and the kenaf composites, as well as their glass transition temperatures $\left(\mathrm{T}_{\mathrm{g}}\right)$. 


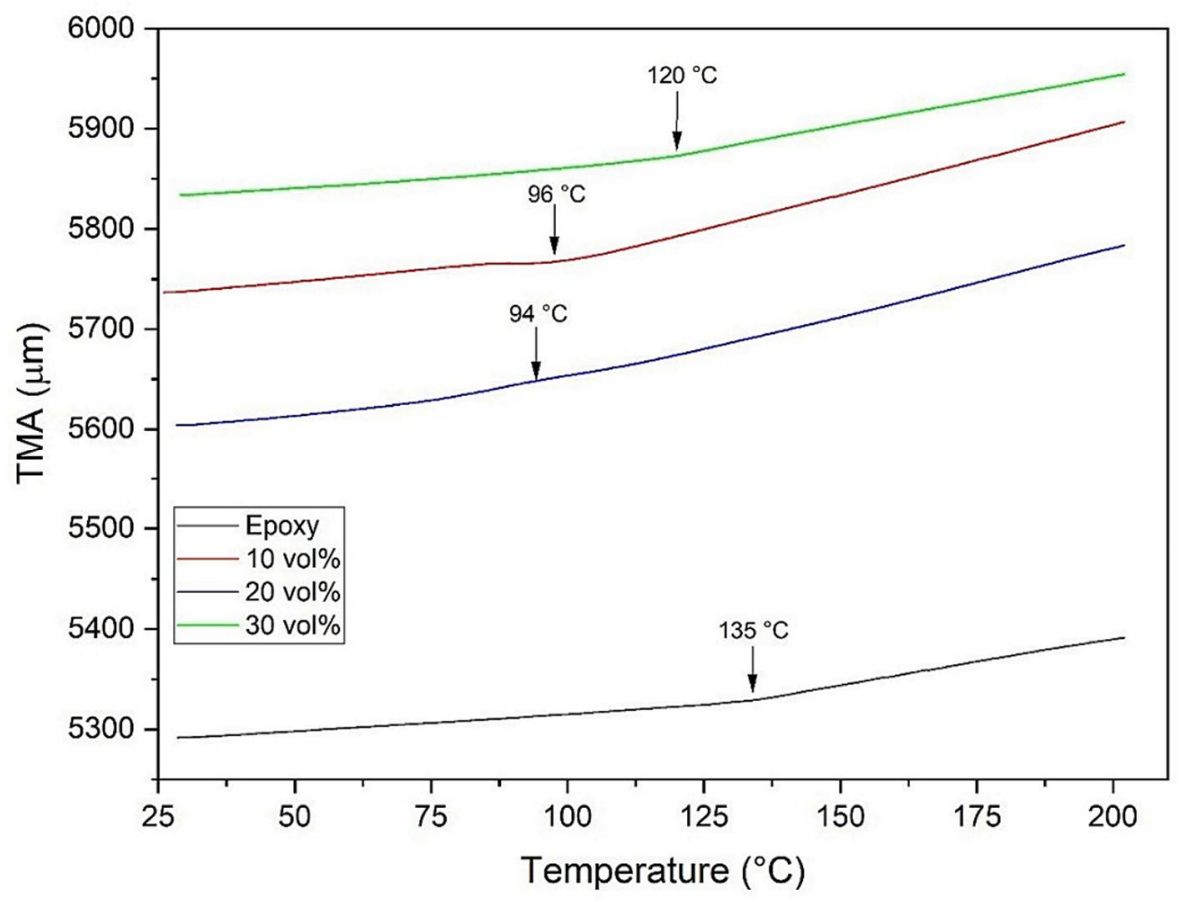

Figure 9. TMA curves obtained for epoxy resin and kenaf composites.

The glass transition temperatures obtained were $135^{\circ} \mathrm{C}$ for the epoxy resin and 96,94 , and $120{ }^{\circ} \mathrm{C}$ for the composites with $10 \mathrm{vol} \%, 20 \mathrm{vol} \%$, and $30 \mathrm{vol} \%$ kenaf reinforcement, respectively. Any factor that can affect the molecular mobility of the material, such as chemical composition, induction of crystallization by stretching, oxidation, addition of fillers, or a material that has a lower molecular mass, can affect the glass transition interval of the polymeric material and its thermal and mechanical behavior [79].

In the case of kenaf fibers, regarding the epoxy composite thermal behavior, the main factor is the addition of fibers as a reinforcing filler to the matrix, thus restricting the epoxy macromolecular mobility.

It was observed that the material undergoes expansion with increasing temperature. The linear thermal expansion coefficient obtained in this work was $112.38 \times 10^{-6} /{ }^{\circ} \mathrm{C}$ for the epoxy resin and $181.16 \times 10^{-6} /{ }^{\circ} \mathrm{C}, 187.02 \times 10^{-6} /{ }^{\circ} \mathrm{C}$, and $116.50 \times 10^{-6} /{ }^{\circ} \mathrm{C}$ for the composites with 10,20 , and $30 \mathrm{vol} \%$ kenaf reinforcement, respectively.

\section{Summary and Conclusions}

Thermal and chemical properties were, for the first time, investigated in kenaf fiber reinforced epoxy matrix composites together with determination of fiber density and microfibrillar angle.

The DSC and TGA results indicated that there was an increase in the thermal stability of the composites with values of the onset $\left(\mathrm{T}_{\text {onset }}\right)$, minimum detected thermal degradation $\left(\mathrm{T}_{\min }\right)$, and maximum rate of thermal degradation $\left(\mathrm{T}_{\max }\right)$ above those of the plain epoxy. Based on these values, a working temperature of $200{ }^{\circ} \mathrm{C}$ is proposed for the kenaf fiber epoxy composites.

FTIR indicates the existence of functional $\mathrm{OH}, \mathrm{CH}, \mathrm{C}-\mathrm{O}$, and $\mathrm{C}-\mathrm{O}-\mathrm{C}$ bands that might be attributed to the kenaf fiber. These bands are known from fibers highly rich in lignin and hemicellulose.

The XRD diffractogram showed characteristic peaks of lignocellulosic fibers. The presence of kenaf fiber peaks was detected at approximately $22^{\circ} 2 \theta$, and through calculations, $44.3 \%$ fiber crystallinity index (CrI) and $7.1^{\circ}$ microfibrillar angle (MFA) were identified. This MFA result might indicate a stronger mechanical property of the fiber. 
Through TMA analysis, it was observed that the addition of kenaf reinforcement at $10 \mathrm{vol} \%$ and $20 \mathrm{vol} \%$ decreased the $\mathrm{T}_{\mathrm{g}}$ of the material, increasing its coefficient of thermal expansion. On the other hand, the $30 \mathrm{vol} \%$ composite presented a higher $\mathrm{T}_{\mathrm{g}}$ and a lower coefficient of thermal expansion.

These results should contribute to the multiple applications expected for epoxy composites reinforced with kenaf fiber, which might display superior thermal stability, as well as comparatively stronger performance and lower thermal expansion, than other commonly used kenaf composites.

Author Contributions: Conceptualization, methodology, investigation, T.T.d.S.; formal analysis and data curation, T.T.d.S., M.P.R., M.F.L., P.H.P.M.d.S., A.P.d.S.; writing—original draft preparation, T.T.d.S., P.H.P.M.d.S., M.P.R; writing-review and editing; L.F.C.N., M.F.L., A.P.d.S. and S.N.M.; supervision, L.F.C.N.; funding, S.N.M.; project administration, L.F.C.N and S.N.M. All authors have read and agreed to the published version of the manuscript.

Funding: This research work is supported by the Brazilian Agency CAPES (Coordenação de Aperfeiçoamento de Pessoal de Nível Superior), Protocol \#001.

Acknowledgments: The authors would like to thank the Navy Research Institute (IPqM) for its cooperation in mechanical and thermal analysis. The authors would also like to thank the company Tapetes São Carlos for the donation of kenaf fibers and the Instituto de Engenharia Nuclear (IENUFRJ) for the XRD analyses.

Conflicts of Interest: The authors declare no conflict of interest.

\section{References}

1. Vigneshwaran, S.; Sundarakannan, R.; John, K.; Johnson, R.D.J.; Prasath, K.A.; Ajith, S.; Arumugaprabu, V.; Uthayakumar, M. Recent advancement in the natural fiber polymer composites: A comprehensive review. J. Clean. Prod. 2020, $277,124109$. [CrossRef]

2. Luz, F.S.; Garcia Filho, F.C.; Del-Rio, M.T.C.; Nascimento, L.F.C.; Pinheiro, W.A.; Monteiro, S.N. Graphene-incorporated natural fiber polymer composites: A first overview. Polymers 2020, 12, 1601. [CrossRef] [PubMed]

3. Hasan, K.M.F.; Horváth, P.G.; Alpar, T. Potential natural fiber polymeric nanobiocomposites: A review. Polymers 2020, $12,1072$. [CrossRef] [PubMed]

4. Zhang, Z.; Cai, S.; Li, Y.; Wang, Z.; Long, Y.; Yu, T.; Shen, Y. High performances of plant fiber reinforced composites-A new insight from hierarchical microstructures. Compos. Sci. Technol. 2020, 194, 108151. [CrossRef]

5. Girijappa, Y.G.T.; Rangappa, S.M.; Parameswaranpillai, J.; Siengchin, S. Natural Fibers as Sustainable and Renewable Resource for Development of Eco-Friendly Composites: A Comprehensive Review. Front. Mater. 2019, 6, 6. [CrossRef]

6. Sanjay, M.R.; Madhu, P.; Jawaid, M.; Senthamaraikannan, P.; Senthil, S.; Pradeep, S. Characterization and properties of natural fiber polymer composites: A comprehensive review. J. Clean. Prod. 2018, 172, 566-581. [CrossRef]

7. Güven, O.; Monteiro, S.N.; Moura, E.A.B.; Drelich, J.W. Re-Emerging Field of Lignocellulosic Fiber Polymer Composites and Ionizing Radiation Technology in their Formulation. Polym. Rev. 2016, 56, 706-736. [CrossRef]

8. Potluri, R.; Krishna, N.C. Potential and Applications of Green Composites in Industrial Space. Mater. Today 2020, 22, 2041-2048.

9. Kumar, R.; Haq, M.I.U.; Raina, A.; Anand, A. Industrial applications of natural fibre-reinforced polymer composites-Challenges and opportunities. Int. J. Sustain. Eng. 2018, 12, 212-220. [CrossRef]

10. Krishna, N.K.; Prasanth, M.; Gowtham, R.; Karthic, S.; Mini, K.M. Enhancement of properties of concrete using natural fibers. Mater. Today 2018, 5, 23816-23823. [CrossRef]

11. Youssef, A.M.; El-Sayed, S.M. Bionanocomposites materials for food packaging applications: Concepts and future outlook. Carbohydr. Polym. 2018, 193, 19-27. [CrossRef] [PubMed]

12. Dunne, R.; Desai, D.; Sadiku, R.; Jayaramudu, J. A review of natural fibres, their sustainability and automotive applications. J. Reinf. Plast. Compos. 2016, 35, 1041-1050. [CrossRef]

13. Zah, R.; Hischier, R.; Leão, A.; Braun, I. Curauá fibers in the automobile industry-A sustainability assessment. J. Clean. Prod. 2007, 15, 1032-1040. [CrossRef]

14. Holbery, J.; Houston, D. Natural-fiber-reinforced polymer composites in automotive applications. JOM 2006, 58, 80-86. [CrossRef]

15. Callister, W.D., Jr.; Rethwisch, D.G. Materials Science and Engineering: An Introduction, 10th ed.; Wiley: Hoboken, NJ, USA, 2018.

16. Fitzgerald, A.; Proud, W.; Kandemir, A.; Murphy, R.; Jesson, D.; Trask, R.; Hamerton, I.; Longana, M. A life cycle engineering perspective on biocomposites as a solution for a sustainable recovery. Sustainability 2021, 13, 1160. [CrossRef]

17. Ramesh, M. Kenaf (Hibiscus cannabinus L.) fibre based bio-materials: A review on processing and properties. Prog. Mater. Sci. 2016, 78-79, 1-92. [CrossRef]

18. Kandemir, A.; Pozegic, T.R.; Hamerton, I.; Eichhorn, S.J.; Longana, M.L. Characterisation of natural fibres for sustainable discontinuous fibre composite materials. Material 2020, 13, 2129. [CrossRef] 
19. Yusoff, R.B.; Takagi, H.; Nakagaito, A.N. Tensile and flexural properties of polylactic acid-based hybrid green composites reinforced by kenaf, bamboo and coir fibers. Ind. Crops Prod. 2016, 94, 562-573. [CrossRef]

20. Mohammed, L.; Ansari, M.N.M.; Pua, G.; Jawaid, M.; Islam, S. A review on natural fiber reinforced polymer composite and its applications. Int. J. Polym. Sci. 2015, 2015, 1-15. [CrossRef]

21. Hao, A.; Zhao, H.; Chen, J.Y. Kenaf/polypropylene nonwoven composites: The influence of manufacturing conditions on mechanical, thermal, and acoustical performance. Compos. Part B Eng. 2013, 54, 44-51. [CrossRef]

22. Meon, M.S.; Othman, M.F.; Husain, H.; Remeli, M.F.; Syawal, M.S.M. Improving Tensile Properties of Kenaf Fibers Treated with Sodium Hydroxide. Procedia Eng. 2012, 41, 1587-1592. [CrossRef]

23. Asumani, O.; Reid, R.G.; Paskaramoorthy, R. The effects of alkali-silane treatment on the tensile and flexural properties of short fibre non-woven kenaf reinforced polypropylene composites. Compos. Part A Appl. Sci. Manuf. 2012, 43, 1431-1440. [CrossRef]

24. Hao, A.; Zhao, H.; Jiang, W.; Yuan, L.; Chen, J.Y. Mechanical properties of kenaf/polypropylene nonwoven composites. J. Polym. Environ. 2012, 20, 959-966. [CrossRef]

25. Islam, M.S.; Church, J.S.; Miao, M. Effect of removing polypropylene fibre surface finishes on mechanical performance of kenaf/polypropylene composites. Compos. Part A Appl. Sci. Manuf. 2011, 42, 1687-1693. [CrossRef]

26. Bernard, M.; Khalina, A.; Ali, A.; Janius, R.; Faizal, M.; Hasnah, K.; Sanuddin, A. The effect of processing parameters on the mechanical properties of kenaf fibre plastic composite. Mater. Des. 2011, 32, 1039-1043. [CrossRef]

27. John, M.J.; Bellmann, C.; Anandjiwala, R.D. Kenaf-polypropylene composites: Effect of amphiphilic coupling agent on surface properties of fibres and composites. Carbohydr. Polym. 2010, 82, 549-554. [CrossRef]

28. Zampaloni, M.; Pourboghrat, F.; Yankovich, S.; Rodgers, B.; Moore, J.; Drzal, L.; Mohanty, A.; Misra, M. Kenaf natural fiber reinforced polypropylene composites: A discussion on manufacturing problems and solutions. Compos. Part A Appl. Sci. Manuf. 2007, 38, 1569-1580. [CrossRef]

29. Shibata, S.; Cao, Y.; Fukumoto, I. Lightweight laminate composites made from kenaf and polypropylene fibres. Polym. Test. 2006, 25, 142-148. [CrossRef]

30. Osman, M.R.; Mazuki, A.A.M.; Akil, H.M.; Ishak, Z.A.M.; Abu Bakar, A. Effect of Chemical Treatment on the Mechanical Properties of Pultruded Kenaf Fibre Reinforced Polyester Composites. Key Eng. Mater. 2013, 594-595, 691-695. [CrossRef]

31. Sapuan, S.; Pua, F.-L.; El-Shekeil, Y.; Al-Oqla, F.M. Mechanical properties of soil buried kenaf fibre reinforced thermoplastic polyurethane composites. Mater. Des. 2013, 50, 467-470. [CrossRef]

32. Ghani, M.; Salleh, Z.; Hyie, K.M.; Berhan, M.; Taib, Y.; Bakri, M. Mechanical properties of kenaf/fiberglass polyester hybrid composite. Procedia Eng. 2012, 41, 1654-1659. [CrossRef]

33. Rassmann, S.; Paskaramoorthy, R.; Reid, R. Effect of resin system on the mechanical properties and water absorption of kenaf fibre reinforced laminates. Mater. Des. 2011, 32, 1399-1406. [CrossRef]

34. Mazuki, A.A.M.; Akil, H.M.; Safiee, S.; Ishak, Z.A.M.; Abu Bakar, A. Degradation of dynamic mechanical properties of pultruded kenaf fiber reinforced composites after immersion in various solutions. Compos. Part B Eng. 2011, 42, 71-76. [CrossRef]

35. Thiruchitrambalam, M.; Alavudeen, A.; Athijayamani, A.; Venkateshwaran, N.; Perumal, A.E. Improving Mechanical Properties of Banana/Kenaf Polyester Hybrid Composites Using Sodium Laulryl Sulfate Treatment. Mater. Phys. Mech. 2009, 8, 165-173.

36. Aziz, S.H.; Ansell, M.P. The effect of alkalization and fibre alignment on the mechanical and thermal properties of kenaf and hemp bast fibre composites: Part 1-Polyester resin matrix. Compos. Sci. Technol. 2004, 64, 1219-1230. [CrossRef]

37. El-Shekeil, Y.; Sapuan, S.; Abdan, K.; Zainudin, E.S. Influence of fiber content on the mechanical and thermal properties of Kenaf fiber reinforced thermoplastic polyurethane composites. Mater. Des. 2012, 40, 299-303. [CrossRef]

38. Batouli, S.M.; Zhu, Y.; Nar, M.; D’Souza, N.A. Environmental performance of kenaf-fiber reinforced polyurethane: A life cycle assessment approach. J. Clean. Prod. 2014, 66, 164-173. [CrossRef]

39. Salleh, F.M.; Hassan, A.; Yahya, R.; Azzahari, A.D. Effects of extrusion temperature on the rheological, dynamic mechanical and tensile properties of kenaf fiber/HDPE composites. Compos. Part B Eng. 2014, 58, 259-266. [CrossRef]

40. Aji, I.S.; Zainudin, E.S.; Sapuan, S.M.; Khalina, A.; Khairul, M.D.; Sapuan, M.S. Study of hybridized kenaf/PALF-reinforced HDPE composites by dynamic mechanical analysis. Polym. Technol. Eng. 2012, 51, 146-153. [CrossRef]

41. Aji, I.; Zainudin, E.; Khalina, A.; Sapuan, S.; Khairul, M.; Sapuan, M.S. Studying the effect of fiber size and fiber loading on the mechanical properties of hybridized kenaf/PALF-reinforced HDPE composite. J. Reinf. Plast. Compos. 2011, 30, 546-553. [CrossRef]

42. Zheng, C.; Xu, Y.Y.; Kawai, T.; Kuroda, S.-I. Effect of polymeric coupling agent on mechanical properties of kenaf fiber/polystyrene composites. Appl. Mech. Mater. 2012, 268, 127-133. [CrossRef]

43. Kwon, H.-J.; Sunthornvarabhas, J.; Park, J.-W.; Lee, J.-H.; Kim, H.-J.; Piyachomkwan, K.; Sriroth, K.; Cho, D. Tensile properties of kenaf fiber and corn husk flour reinforced poly(lactic acid) hybrid bio-composites: Role of aspect ratio of natural fibers. Compos. Part B Eng. 2014, 56, 232-237. [CrossRef]

44. Shukor, F.; Hassan, A.; Islam, S.; Mokhtar, M.; Hasan, M. Effect of ammonium polyphosphate on flame retardancy, thermal stability and mechanical properties of alkali treated kenaf fiber filled PLA biocomposites. Mater. Des. 2014, 54, 425-429. [CrossRef]

45. Han, S.O.; Karevan, M.; Bhuiyan, A.; Park, J.H.; Kalaitzidou, K. Effect of exfoliated graphite nanoplatelets on the mechanical and viscoelastic properties of poly(lactic acid) biocomposites reinforced with kenaf fibers. J. Mater. Sci. 2011, 47, 3535-3543. [CrossRef]

46. Hasfalina, C.; Maryam, R.; Man, H.C.; Rashid, M. Adsorption of Copper (II) From Aqueous Medium in Fixed-Bed Column by Kenaf Fibres. APCBEE Procedia 2012, 3, 255-263. [CrossRef] 
47. Sukyai, P.; Sriroth, K.R.; Lee, B.H.; Hyun, J.K. The Effect of Bacterial Cellulose on the Mechanical and Thermal Expansion Properties of Kenaf/Polylactic Acid Composites. Appl. Mech. Mater. 2011, 117-119, 1343-1351. [CrossRef]

48. Huda, M.S.; Drzal, L.T.; Mohanty, A.K.; Misra, M. Effect of fiber surface-treatments on the properties of laminated biocomposites from poly(lactic acid) (PLA) and kenaf fibers. Compos. Sci. Technol. 2008, 68, 424-432. [CrossRef]

49. Ochi, S. Mechanical properties of kenaf fibers and kenaf/PLA composites. Mech. Mater. 2008, 40, 446-452. [CrossRef]

50. Nishino, T.; Hirao, K.; Kotera, M. X-ray diffraction studies on stress transfer of kenaf reinforced poly(l-lactic acid) composite. Compos. Part A Appl. Sci. Manuf. 2006, 37, 2269-2273. [CrossRef]

51. Nishino, T.; Hirao, K.; Kotera, M.; Nakamae, K.; Inagaki, H. Kenaf reinforced biodegradable composite. Compos. Sci. Technol. 2003, 63, 1281-1286. [CrossRef]

52. Aizan, M.Z.N.; Akhmar, S.A.S.Z.; Muhiddin, A.M.; Hazwani, Z.N.; Sarah, J.S. Study on cure characteristics and mechanical behaviours of kenaf fibre reinforced natural rubber composites. Adv. Mater. Res. 2013, 812, 66-72. [CrossRef]

53. El-Shekeil, Y.; Sapuan, S.; Jawaid, M.; Al-Shuja'A, O. Influence of fiber content on mechanical, morphological and thermal properties of kenaf fibers reinforced poly(vinyl chloride)/thermoplastic polyurethane poly-blend composites. Mater. Des. 2014, 58, 130-135. [CrossRef]

54. Park, J.-M.; Son, T.Q.; Jung, J.-G.; Hwang, B.-S. Interfacial evaluation of single Ramie and Kenaf fiber/epoxy resin composites using micromechanical test and nondestructive acoustic emission. Compos. Interfaces 2006, 13, 105-129. [CrossRef]

55. Keshk, S.; Suwinarti, W.; Sameshima, K. Physicochemical characterization of different treatment sequences on kenaf bast fiber. Carbohydr. Polym. 2006, 65, 202-206. [CrossRef]

56. Sgriccia, N.; Hawley, M. Thermal, morphological, and electrical characterization of microwave processed natural fiber composites. Compos. Sci. Technol. 2007, 67, 1986-1991. [CrossRef]

57. Chin, C.; Yousif, B. Potential of kenaf fibres as reinforcement for tribological applications. Wear 2009, 267, 1550-1557. [CrossRef]

58. Xue, Y.; Du, Y.; Elder, S.; Wang, K.; Zhang, J. Temperature and loading rate effects on tensile properties of kenaf bast fiber bundles and composites. Compos. Part B Eng. 2009, 40, 189-196. [CrossRef]

59. Abu Bakar, M.A.; Ahmad, S.; Kuntjoro, W. The mechanical properties of treated and untreated kenaf fibre reinforced epoxy composite. J. Biobased Mater. Bioenergy 2010, 4, 159-163. [CrossRef]

60. Mutasher, S.A.; Poh, A.; Than, A.M.; Law, J. The effect of alkali treatment mechanical properties of kenaf fiber epoxy composite. Key Eng. Mater. 2011, 471-472, 191-196. [CrossRef]

61. Abdullah, A.H.; Alias, S.K.; Jenal, N.; Abdan, K.; Ali, A. Fatigue behavior of kenaf fibre reinforced epoxy composites. Eng. J. 2012, 16, 105-114. [CrossRef]

62. Suriani, M.; Ali, A.; Khalina, A.; Sapuan, S.; Abdullah, S. Detection of defects in kenaf/epoxy using infrared thermal imaging technique. Procedia Chem. 2012, 4, 172-178. [CrossRef]

63. Davoodi, M.; Sapuan, S.; Ahmad, D.; Ali, A.; Khalina, A.; Jonoobi, M. Mechanical properties of hybrid kenaf/glass reinforced epoxy composite for passenger car bumper beam. Mater. Des. 2010, 31, 4927-4932. [CrossRef]

64. Chen, Z.; Luo, J.; Huang, Z.; Cai, C.; Tusiime, R.; Li, Z.; Wang, H.; Cheng, C.; Liu, Y.; Sun, Z.; et al. Synergistic toughen epoxy resin by incorporation of polyetherimide and amino groups grafted MWCNTs. Compos. Commun. 2020, 21, 100377. [CrossRef]

65. González-Garcia, F.; Miguez, E.; Soares, B.G. Caracterização do sistema éter diglicidílico do bisfenol A/poliaminas alifáticas. Polímeros 2005, 15, 261-267. [CrossRef]

66. Fonseca, E.; da Silva, V.D.; Klitzke, J.; Schrekker, H.; Amico, S. Imidazolium ionic liquids as fracture toughening agents in DGEBA-TETA epoxy resin. Polym. Test. 2020, 87, 106556. [CrossRef]

67. Kerche, E.F.; da Silva, V.D.; Fonseca, E.; Salles, N.A.; Schrekker, H.S.; Amico, S.C. Epoxy-based composites reinforced with imidazolium ionic liquid-treated aramid pulp. Polymer 2021, 226, 123787. [CrossRef]

68. ASTM International. E1131-20 Standard Test Method for Compositional Analysis by Thermogravimetry; ASTM International: West Conshohocken, PA, USA, 2020. [CrossRef]

69. Donaldson, L. Microfibril Angle: Measurement, Variation and Relationships-A Review. IAWA J. 2008, 29, 345-386. [CrossRef]

70. Sarén, M.-P.; Serimaa, R. Determination of microfibril angle distribution by X-ray diffraction. Wood Sci. Technol. 2006, 40, 445-460. [CrossRef]

71. Segal, L.; Creely, J.; Martin, A.; Conrad, C. An empirical method for estimating the degree of crystallinity of native cellulose using the X-ray diffractometer. Text. Res. J. 1959, 29, 786-794. [CrossRef]

72. ASTM International. E831-19 Standard Test Method for Linear Thermal Expansion of Solid Materials by Thermomechanical Analysis; ASTM International: West Conshohocken, PA, USA, 2019. [CrossRef]

73. Monteiro, S.N.; Calado, V.; Margem, F.M.; Rodriguez, R.J. Thermogravimetric stability behavior of less common lignocellulosic fibers-A review. J. Mater. Res. Technol. 2012, 1, 189-199. [CrossRef]

74. Salem, I.A.S.; Rozyanty, A.R.; Betar, B.; Adam, T.; Mohammed, M. Study of the effect of surface treatment of kenaf fiber on chemical structure and water absorption of kenaf filled unsaturated polyester composite. J. Phys. Conf. Ser. 2017, 908, 012001. [CrossRef]

75. Ribeiro, M.P.; Neuba, L.D.M.; da Silveira, P.H.P.M.; da Luz, F.S.; Figueiredo, A.B.-H.D.S.; Monteiro, S.N.; Moreira, M.O. Mechanical, thermal and ballistic performance of epoxy composites reinforced with Cannabis sativa hemp fabric. J. Mater. Res. Technol. 2021, 12, 221-233. [CrossRef] 
76. Rozyanty, A.; Zhafer, S.; Shayfull, Z.; Nainggolan, I.; Musa, L.; Zheing, L. Effect of water and mechanical retting process on mechanical and physical properties of kenaf bast fiber reinforced unsaturated polyester composites. Compos. Struct. 2021, 257, 113384. [CrossRef]

77. Zhan, J.; Li, J.; Wang, G.; Guan, Y.; Zhao, G.; Lin, J.; Naceur, H.; Coutellier, D. Review on the performances, foaming and injection molding simulation of natural fiber composites. Polym. Compos. 2021, 42, 1305-1324. [CrossRef]

78. Monteiro, S.N.; Lopes, F.P.D.; Barbosa, A.P.; Bevitori, A.B.; Da Silva, I.L.A.; Da Costa, L.L. Natural lignocellulosic fibers as engineering materials-An overview. Metall. Mater. Trans. A 2011, 42, 2963-2974. [CrossRef]

79. Saba, N.; Jawaid, M. A review on thermomechanical properties of polymers and fibers reinforced polymer composites. J. Ind. Eng. Chem. 2018, 67, 1-11. [CrossRef] 